\title{
EFEK SUHU PENGERINGAN DAN KONSENTRASI SUKROSA TERHADAP KARAKTERISTIK PERMEN JELLY DAUN KELOR (Moringa oleifera)
}

\author{
Neneng Suliasih \\ Supli Effendi \\ Vania \\ Program Studi Teknologi Pangan, Fakultas Teknik, Universitas Pasundan, Jl. Dr.Setiabudi No 93, Bandung, 40153, \\ Indonesia \\ E-mail : nenengsuliasih@unpas.ac.id
}

\begin{abstract}
Abstrak
Tujuan penelitian ini adalah untuk mengetahui pengaruh rasio tepung talas:jamur tiram putih dan konsentrasi kuning telur terhadap karakteristik cookies. Model rancangan percobaan yang digunakan dalam penelitian pembuatan cookies adalah Rancangan Acak Kelompok (RAK) dengan 2 (dua) faktor, dilakukan dengan 3 (tiga) kali ulangan, sehingga diperoleh 27 satuan percobaan. Faktor percobaan terdiri dari rasio jamur tiram putih:tepung talas $(1: 2,1: 1,2: 1)$ dan konsentrasi kuning telur $(6 \%, 9 \%, 12 \%)$. Hasil penelitian yang didapat bahwa rasio tepung talas:jamur tiram putih berpengaruh terhadap warna, rasa, tekstur, dan respon kimia pada cookies. Konsentrasi kuning telur berpengaruh terhadap aroma cookies. Interaksi antara rasio tepung talas:jamur tiram putih dan konsentrasi kuning telur berpengaruh terhadap warna dan rasa cookies. Perlakuan terbaik diperoleh pada perlakuan rasio jamur tiram putih:tepung talas 1:2 dan konsentrasi kuning telur 6\%. Cookies hasil eksperimen terbaik mengandung kadar air 2,48\%, kadar protein 25,08\%, kadar serat 2,26\%, dan kadar karbohidrat 71,46\%.

Kata kunci : Cookies, tepung talas, jamur tiram putih, kuning telur.
\end{abstract}

\begin{abstract}
The purpose of this research is to know the effect of ratio taro flour:white oyster mushrooms and egg yolk concentration on the characteristics of cookies. The model of experimental design used in the research of making cookies is Randomized Block Design (RAK) with 2 (two) factors, conducted with 3 (three) times repeatitions, so obtained 27 experimental unit. Factors experiments consists of ratio of white oyster mushrooms:taro flour $(1: 2,1: 1,2: 1)$ and egg yolk concentration $(6 \%, 9 \%, 12 \%)$. The research results obtained that ratio of white oyster mushrooms:taro flour affect color, taste, texture and chemical response of the cookies. Concentration of egg yolk affect flavors of the cookies. The interaction between the ratio of white oyster mushrooms:taro flour and egg yolk concentration affect on color and taste of the cookies. The best treatment is taken from ratio of white oyster mushrooms:taro flour 1:2 with egg yolk concentration is $6 \%$. Cookies result of best experiment contain water content $2,48 \%$, protein content $25,08 \%$, fiber content $2,26 \%$ and carbohydrate content $71,46 \%$.
\end{abstract}

Keywords: Cookies, taro flour, white oyster mushrooms, egg yolk

\section{Pendahuluan}

Industri pangan masih memiliki ketergantungan pada tepung terigu, seperti dalam pembuatan mie, biskuit, roti dan cookies. Tepung terigu yang berbahan baku gandum ini, tidak dapat diproduksi di Indonesia, karena jenis serealia ini tidak dapat tumbuh di Indonesia. Untuk memanfaatkan bahan baku lokal dapat diatasi dengan menggunakan talas (Colocasia esculenta (L) Schot) yang digunakan sebagai tepung.

Umbi talas memiliki keunggulan yaitu kemudahan patinya untuk dicerna. Hal ini disebabkan talas memiliki ukuran granula pati yang sangat kecil yaitu $1-4 \mu \mathrm{m}$. Ukuran granula pati yang kecil dapat bermanfaat mengatasi masalah pencernaan (Nurbaya dan Estiasih,2013). Umbi talas berpotensi sebagai sumber karbohidrat yang cukup tinggi. Umbi talas juga mengandung lemak, vitamin $\left(\mathrm{A}, \mathrm{B}_{1}\right.$ dan sedikit vitamin C), dan mineral dalam jumlah sedikit (Richana,2012).
Talas memiliki potensi untuk dapat digunakan sebagai bahan baku tepung-tepungan karena memiliki kandungan pati yang tinggi, yaitu sekitar 70-80\% (Nurbaya dan Estiasih,2013). Kandungan serat talas juga cukup tinggi. Kehadiran serat ini sangat baik untuk menjaga kesehatan saluran cerna. Secara tradisional, masyarakat di kepulauan Pasifik dan Hawaii telah menggunakan talas sebagai ingredien untuk makanan bayi. Talas memiliki banyak getah (gum). Keberadaan gum ini, dan kadar amilopektinnya yang lebih tinggi dari amilosa menyebabkan rasa dan tekstur talas menjadi lengket dan pulen (Saptoningsih,2014). Pati umbi talas memiliki kadar air 13,18\%, kadar amilosa 5,55\%, dan kadar amilopektin 74,45\% (Rahmawati dkk,2012). Selain itu, talas juga sering dikonsumsi sebagai makanan pokok bagi orang-orang yang alergi terhadap biji-bijian tertentu yang mengandung gluten terutama gandum. Konsumsi umbi-umbian sebagai sumber karbohidrat selain gandum 
dan bahan pangan lain yang mengandung gluten dapat mereduksi Coeliac disease (CD) atau reaksi hipersensitif lainnya (Apriani dkk, 2011).

Selain umbi talas, jamur tiram juga bahan pangan yang cukup populer karena memiliki rasa yang enak dan juga mengandung nilai gizi yang tinggi. Jamur tiram mengandung kadar protein sebesar $10-30 \%$ dan garam mineral yang kadarnya lebih tinggi dibandingkan dengan daging kambing. Jamur merupakan sayuran lunak yang banyak menyimpan riboflavin atau vitamin B2. Riboflavin berperan dalam produksi sel-sel sistem kekebalan tubuh (Apriadji,2007). Serat jamur sangat baik untuk pencernaan, kandungan seratnya mencapai 7,424,6\% (Alex, 2011). Setiap 100 gram jamur kering juga mengandung protein $10,5-30,4 \%$, lemak $1,7-2,2 \%$, karbohidrat $56,6 \%$, tiamin $0,2 \mathrm{mg}$, riboflavin $4,7-4,9$ $\mathrm{mg}$, niasin 77,2 mg, kalsium $314 \mathrm{mg}$, dan kalori 367 (Suwito, 2006).

Konsumsi jamur tiram dapat dilakukan dengan berbagai cara, tergantung selera dan tujuan dari konsumsi jamur yang dimaksud. Ada yang dikonsumsi segar biasanya untuk lauk yang dicampur dengan daging, ikan atau sayuran lain. tersebut hanya perlu disiram dengan air panas. Pengolahan jamur tiram yang beragam ini, disebabkan harga jual jamur yang relatif murah dan dapat dijangkau yakni sekitar Rp 12.000/kg (Puspitasari dkk,2014).

Jamur tiram memiliki umur simpan yang pendek atau cepat mengalami kerusakan. Produk hortikultura seperti buah dan sayur adalah produk yang masih melakukan aktivitas metabolisme setelah dipanen. Kerusakan produk dapat disebabkan kontaminasi mikroba, pengaruh suhu dan udara, serta kadar air (Puspitasari dkk,2014). Oleh karena itu, perlu dilakukan diversifikasi pangan jamur untuk memperpanjang umur simpan jamur seperti dengan mengolahnya menjadi cookies.

Umbi talas dan jamur ini akan menjadi bahan baku cookies dengan menambahkan kuning telur sebagai bahan tambahannya. Menurut Rosida dan Manggarani (2014), penggunaan kuning telur akan menghasilkan manis yang lebih empuk daripada menggunakan seluruh bagian telur. Lesitin dalam kuning telur dapat berfungsi sebagai emulsifier pada pembuatan cookies manis, sehingga membantu menyebarkan lemak keseluruh bagian adonan yang lebih baik lagi. Disamping itu telur juga menambah nilai gizi produk akhir karena mengandung protein, lemak dan mineral.

Produk cookies harus memiliki tekstur renyah sehingga dalam pembuatannya dibutuhkan penambahan emulsifier. Salah satu emulsifier yang banyak digunakan adalah kuning telur. Menurut Widyastuti dkk (2015) fungsi penambahan kuning telur yaitu sebagai bahan yang dapat membantu memperbaiki tekstur biskuit menjadi lebih empuk. Untuk itu, penambahan kuning telur dalam proses pembuatan biskuit ini penting diperhatikan. Hal ini dikarenakan kuning telur mengandung lesitin yang terdapat dalam bentuk kompleks lesitin-protein yang berperan sebagai emulsifier sehingga menghasilkan biskuit yang lebih renyah.

Cookies merupakan salah satu jenis camilan atau makanan ringan yang banyak disukai oleh sebagian besar masyarakat mulai balita sampai dewasa. Komsumsi ratarata cookies di Indonesia adalah $0,40 \mathrm{~kg} /$ tahun. Berkenaan dengan bahan pembuatan cookies, keempukan dan kelembutan cookies ditentukan terutama oleh tepung terigu, gula dan lemak. Pensubstitusian maupun penambahan bahan terhadap tepung terigu tidak berpengaruh secara signifikan. Penelitian terdahulu telah berhasil menambahkan puree waluh hingga 50\% dari berat tepung terigu yang digunakan dan substitusi tepung hotong hingga $100 \%$ dari berat tepung terigu yang digunakan (Millah dkk, 2014). Hal ini memberikan peluang untuk menambahkan jamur tiram pada adonan cookies dengan menggunakan tepung talas dan kuning telur sebagai pengganti tepung terigu. Tepung talas akan menggantikan peran tepung terigu dalam membentuk kerangka cookies dan kuning telur berperan sebagai emulsifier menggantikan tepung terigu yang memiliki gluten. Oleh karena itu, perlu dilakukan penelitian lebih lanjut untuk menentukan proporsi yang tepat dalam pembuatan cookies dari jamur dengan tepung talas dan penambahan kuning telur untuk memperoleh karakteristik kimia dan organoleptik terbaik.

\section{Metode Penelitian}

Penelitian ini terdiri dari dua tahap, yaitu penelitian pendahuluan dan penelitian utama. Pada penelitian pendahuluan dilakukan pembuatan tepung talas dan penentuan formulasi terbaik. Analisis respon yang dilakukan pada pembuatan tepung adalah jumlah rendemen dan kadar air tepung. Pada penentuan formulasi dengan perbandingan jamur:tepung talas (1:1) dibuat 3 formulasi yaitu formula I (gula pasir, garam, masako), formula II (gula pasir), dan formula III (gula merah), secara keseluruhan dapat dilihat pada Tabel 1.

Tabel 1. Formulasi Penelitian Pendahuluan

\begin{tabular}{|l|l|l|l|l|}
\hline \multirow{2}{*}{ No. } & \multirow{2}{*}{ Bahan } & \multicolumn{3}{|l|}{ Jumlah (\%) } \\
\cline { 3 - 5 } & & $\begin{array}{l}\text { Formula } \\
\text { I }\end{array}$ & $\begin{array}{l}\text { Formula } \\
\text { II }\end{array}$ & $\begin{array}{l}\text { Formula } \\
\text { III }\end{array}$ \\
\hline 1. & Jamur & 25 & 25 & 25 \\
\hline 2. & Tepung Talas & 25 & 25 & 25 \\
\hline 3. & Margarin & 20 & 20 & 20 \\
\hline 4. & Kuning telur & 9 & 9 & 9 \\
\hline 5 & $\begin{array}{l}\text { Susu Bubuk } \\
\text { Dancow }\end{array}$ & 8 & 8 & 8 \\
\hline 6. & Gula pasir & 1 & 9 & - \\
\hline 7. & Garam & 3 & - & - \\
\hline 8. & Gula Merah & - & - & 9 \\
\hline 9. & $\begin{array}{l}\text { Bumbu } \\
\text { serbuk }\end{array}$ & 5 & - & - \\
\hline 10. & Masako & & & \\
\hline 11. & Maizena & 3 & 3 & 3 \\
\hline
\end{tabular}


Selanjutnya dilakukan uji kesukaan dengan respon rasa, warna, aroma, dan tekstur oleh 30 orang panelis.

Penelitian utama terdiri dari dua faktor, yaitu perbandingan jamur dengan tepung talas (t) dan konsentrasi kuning telur (s). Faktor pertama terdiri dari tiga taraf dan faktor kedua terdiri dari tiga taraf. Faktor perbandingan jamur dengan tepung talas $(\mathrm{t})$ terdiri dari :

$\mathrm{t}_{1}=$ perbandingan jamur dengan tepung talas $1: 2$

$\mathrm{t}_{2}=$ perbandingan jamur dengan tepung talas $1: 1$

$\mathrm{t}_{3}=$ perbandingan jamur dengan tepung talas $2: 1$

Faktor konsentrasi kuning telur (s) terdiri dari :

$\mathrm{s}_{1}=$ konsentrasi kuning telur $6 \%$

$\mathrm{s}_{2}=$ konsentrasi kuning telur $9 \%$

$\mathrm{s}_{3}=$ konsentrasi kuning telur $12 \%$

Rancangan percobaan yang digunakan pada penelitian ini adalah pola faktorial $(3 \times 3)$ dalam Rancangan Acak Kelompok (RAK) dengan 3 kali pengulangan. Adapun variabel yang digunakan adalah perbandingan jamur dengan tepung talas $(\mathrm{t})$ sebanyak 3 taraf dan konsentrasi kuning telur (s) sebanyak 3 taraf. Rancangan respon yang akan dilakukan pada penelitian ini meliputi respon kimia, dan respon organoleptik. Respon kimia yang dilakukan meliputi kadar karbohidrat metode Luff Schoorls, kadar serat metode Gravimetri, kadar protein metode Kjeldhal, kadar air, metode Gravimetri. Uji organoleptik yang digunakan dalam penelitian ini adalah uji kesukaan panelis terhadap respon produk yang diuji dengan skala hedonik yang ditransformasikan ke skala numerik. Panelis yang digunakan untuk menguji sebanyak 30 orang dan respon yang diuji terhadap cookies yang dihasilkan meliputi warna, aroma, rasa, dan tekstur.

\section{Hasil dan Pembahasan \\ Hasil Penelitian Pendahuluan}

Penelitian pendahuluan dilakukan pembuatan tepung talas, kemudian dilakukan penentuan kadar air dan rendemennya serta menetapkan formula terbaik cookies yang akan digunakan pada penelitian utama. Pada penelitian pendahuluan penentuan formula terbaik dilakukan pengujian secara organoleptik berdasarkan tingkat kesukaan panelis (hedonik) dengan atribut pengujian terhadap warna, rasa, tekstur, dan aroma.

\section{Kadar Air dan Rendemen}

Tabel 2. Kadar air dan Rendemen Tepung Talas

\begin{tabular}{|l|c|}
\hline \multicolumn{1}{|c|}{ Komponen } & Hasil (\%) \\
\hline Kadar Air & 9,17 \\
\hline Rendemen & 42,29 \\
\hline
\end{tabular}

Berdasarkan hasil penelitian yang dilakukan didapatkan hasil rendemen tepung talas sebesar $42,29 \%$ dengan kadar air sebesar 9,17\%. Hasil penelitian ini sesuai dengan SNI 01-3751-2009 syarat mutu tepung terigu maksimal 14\% hal ini berkaitan dengan daya awet tepung yang akan digunakan untuk pembuatan produk.

Kadar air tepung talas yang dihasilkan dalam penelitian ini tidak berbeda jauh dengan hasil penelitian Koswara (2013), yaitu tepung talas memiliki kadar air sebesar 8,49 $\pm 0,05$. Menurut Yuliatmoko dan Satyatama (2012), hasil penelitian menunjukan tepung talas Lampung memiliki rendemen 34\%. Berat rendemen tepung yang dihasilkan dalam penelitian ini tidak berbeda jauh dengan hasil penelitian yang dilakukan oleh Ali (1996) yaitu, berkisar 36,50-38,76 persen. Nilai rendemen merupakan parameter yang sangat penting guna mengetahui nilai ekonomis suatu produk. Semakin tinggi rendemennya maka semakin tinggi nilai ekonomis produk tersebut, dan semakin rendah angka rendemennya maka produk tersebut bisa dianggap kurang bernilai ekonomis.

Rendemen dihasilkan dalam penelitian ini mendekati dengan yang dilakukan oleh ali (1996) dengan perolehan rendemen yang lebih besar yaitu sebesar $42,29 \%$. Hal ini dapat dipengaruhi oleh varietas talas yang berbeda, di samping faktor lain seperti iklim, kesuburan tanah, umur panen, dan lain-lain sehingga mempengaruhi rendemen yang dihasilkan.

Proses pengeringan pada pembuatan tepung merupakan salah satu tahapan yang krusial, karena menentukan kualitas dan keawetan dari produk olahan selanjutnya dari tepung tersebut. Suhu dan waktu pengeringan merupakan faktor penting dalam pengeringan yang akan mempengaruhi mutu produk akhir (Heldman dan Lund, 2007). Penepungan talas juga dapat mengurangi kerugian karena panen raya (Hartati dan Prana, 2003). Proses pengeringan yang paling optimal menurut Mohamed dan Hussein (1994) dilakukan pada suhu pengeringan $60^{\circ} \mathrm{C}$ selama 22 jam, yang pada akhirnya akan didapatkan kadar air tepung $\pm 9,89 \%$.

Kadar air merupakan pemegang peranan penting, kecuali temperatur maka aktivitas air mempunyai tempat tersendiri dalam proses pembusukan dan ketengikan. Kerusakan bahan makanan pada umumnya merupakan proses mikrobiologis, kimiawi, enzimatik atau kombinasi antara ketiganya. Berlangsungnya ketiga proses tersebut memerlukan air dimana kini telah diketahui bahwa hanya air bebas yang dapat membantu berlangsungnya proses tersebut (Tabrani,1997).

Penentuan kadar air untuk berbagai bahan berbedabeda metodenya tergantung pada sifat bahan. Misalnya: 1 . Untuk bahan yang tidak tahan panas, berkadar gula tinggi, berminyak dan lain-lain penentuan kadar air dapat dilakukan dengan menggunakan oven vakum dengan suhu rendah. 2. Untuk bahan yang mempunyai kadar air tinggi dan mengandung senyawa volatil (mudah menguap) penentuan kadar air dilakukan dengan cara destilasi dengan pelarut tertentu yang berat jenisnya lebih rendah daripada berat jenis air. Untuk bahan cair yang berkadar gula tinggi, penentuan kadar air dapat dilakukan dengan menggunakan reflaktometer,dsb (Winarno, 1997).

\section{Uji Organoleptik}

Pemilihan formulasi cookies ini dilakukan dengan menggunakan uji organoleptik yang di uji oleh 30 panelis. Atribut yang digunakan adalah warna, rasa, tekstur, dan aroma. Berdasarkan hasil analisis variasi menunjukan bahwa formula berpengaruh terhadap rasa tapi tidak 
berpengaruh terhadap warna, tekstur, dan aroma, secara keseluruhan dapat dilihat pada Tabel 3.

Tabel 1. Hasil Uji Organoleptik Cookies pada Penelitian Pendahuluan

\begin{tabular}{|c|c|c|c|c|}
\hline Formula & Warna & Rasa & Tekstur & Aroma \\
\hline F1 & $4,07 \mathrm{a}$ & $3,23 \mathrm{a}$ & $3,87 \mathrm{a}$ & $4,33 \mathrm{a}$ \\
\hline $\mathrm{F} 2$ & $4,17 \mathrm{a}$ & $4,27 \mathrm{~b}$ & $4,30 \mathrm{a}$ & $4,27 \mathrm{a}$ \\
\hline F3 & $4,50 \mathrm{a}$ & $3,63 \mathrm{a}$ & $4,20 \mathrm{a}$ & $4,20 \mathrm{a}$ \\
\hline
\end{tabular}

a. Warna

Berdasarkan Tabel 3 menunjukan bahwa variasi formula 1 , formula 2 , dan formula 3 tidak berpengaruh nyata terhadap atribut warna cookies yang dihasilkan. Cookies memiliki warna coklat yang mirip satu sama lain dikarenakan persentase tepung talas, jamur tiram, dan kuning telur yang digunakan dalam formula pembuatan cookies adalah sama yaitu sebesar $25 \%$ tepung talas, $25 \%$ jamur tiram, dan $9 \%$ kuning telur.

Warna dapat memberikan petunjuk mengenai perubahan kimia dalam makanan, seperti pencoklatan dan pengkaramelan (Kartini, 2006). Warna merupakan sifat kenampakan yang ditandai oleh distribusi spectrum cahaya. Oleh karena itu warna dapat dilihat atau dinilai hanya jika ada sinar atau cahaya. Warna mempunyai kekuatan yang besar dalam menentukan opini terhadap produk terutama makanan (Utami,1999).

Menurut Standar Nasional Indonesia (SNI 013743-1995) gula merah memiliki kadar air maksimal $10 \%$, gula reduksi maksimal 10\%, dan sukrosa minimal 77\%. Menurut Standar Nasional Indonesia (SNI 01-31402001) syarat mutu gula kristal putih memiliki polarisasi minimal 99,5\%. Polarisasi menunjukan kadar sukrosa dalam gula, semakin tinggi polarisasi semakin tinggi kadar gulanya. Batasan minimal kadar polarisari adalah $99,5 \%$.

Menurut Winarno (2004), sukrosa akan mengalami karamelisasi apabila terkena panas tinggi. Karamelisasi merupakan salah satu reaksi pencoklatan enzimatis. Selama proses pemanasan dan pendidihan akan terjadi reaksi maillard pada suhu $118^{\circ} \mathrm{C}-121^{\circ} \mathrm{C}$, selama $30-45$ menit.

Pada penambahan sukrosa pada proses karamelisasi yang terjadi yaitu mula - mula air dalam sukrosa akan terus menguap sampai menjadi lelehan atau leburan sukrosa dengan pemanasan secara terus menerus. Reaksi karamelisasi adalah reaksi yang terjadi karena pemanasan gula pada temperature diatas titik carnya yang akan menghasilkan perubahan warna menjadi warna gelap sampai coklat (Tranggono dan Sutardi, 1989).

Gula merah mengandung sukrosa dan gula putih adalah sukrosa. Semakin tinggi kandungan sukrosa maka semakin besar terjadinya reaksi karamelisasi yang menyebabkan cookies berwarna coklat. Oleh karena itu, cookies dengan formulasi gula putih pada formula 2 agak lebih coklat tua dibanding cookies dengan gula merah formula 3. Sedangkan pada formula 1 yang menggunakan bumbu masako, gula pasir, dan garam memiliki warna yang mirip dengan formula 2. Warna yang diharapkan pada cookies ini adalah coklat muda.

\section{b. Rasa}

Berdasarkan Tabel 13 menunjukan bahwa atribut rasa berbeda nyata pada formula 2 tetapi tidak berbeda nyata pada formula 1 dan 3 . Hal ini menunjukan formula 2 lebih disukai dari segi rasa dilihat dari pengaruh nyata terhadap rasa cookies yang dihasilkan. Rasa pada formula 2 dan 3 dipengaruhi oleh adanya gula pasir dan gula merah. Sedangkan pada formula 3 dipengaruhi oleh adanya gula pasir, garam, dan bumbu serbuk Masako, sehingga rasa cookies yang dihasilkan mempengaruhi respon panelis.

Sukrosa berfungsi sebagai humektan, membantu pembentukan tekstur, memberi flavor melalui reaksi pencoklatan, memberi rasa manis (Afriananda,2011). Cookies dengan gula pasir memberikan rasa yang lebih manis dibandingkan dengan menggunakan gula merah.

Masako adalah bumbu kaldu penyedap yang dibuat dengan perpaduan antara daging segar berkualitas, bumbu dan rempah pilihan. Bumbu ini kurang cocok digunakan untuk penambah citarasa pada cookies talas jamur sehingga kurang diminati oleh panelis.

Rasa merupakan atribut sensori yang tidak dapat dilepaskan dari keseluruhan cita rasa produk makanan. Kenikmatan produk makanan tidak dapat diperoleh jika tidak mencicipi rasanya. Umumnya bahan pangan tidak hanya terdiri dari satu rasa saja akan tetapi gabungan dari berbagai macam rasa yang terpadu sehingga menimbulkan cita rasa makanan yang utuh. Faktor dan konsistensi suatu bahan makanan akan mempengaruhi cita rasa yang ditimbulkan oleh bahan tersebut. Perubahan yang terjadi pada cita rasa bahan pangan biasanya lebih kompleks daripada yang terjadi pada warna bahan pangan (Winarno, 1997).

Menurut Kartika (1988), penerimaan panelis terhadap rasa yang berbeda: (1) Intensitas rasa asam tergantung dari ion $\mathrm{H}^{+}$yang dihasilkan, rasa asin dihasilkan oleh garam-garam organik, rasa manis dihasilkan oleh senyawa alifatik, dan rasa pahit dihasilkan oleh alkaloid-alkaloid, (2) Suhu, dapat mempengaruhi kemampuan kuncup cecapan untuk menangkap rangsangan rasa, (3) Konsentrasi, setiap orang mempunyai batas konsentrasi terendah terhadap suhu suatu rasa agar masih bisa dirasakan, dan (4) Interaksi komponen rasa yang lain, komponen rasa yang lain akan bereaksi dengan komponen rasa primer.

\section{c. Tekstur}

Tekstur dan konsistensi suatu bahan pangan akan mempengaruhi cita rasa yang ditimbulkan oleh bahan tersebut. Berdasarkan pada Tabel 13 menunjukan bahwa variasi formula 1 , formula 2 , dan formula 3 tidak berpengaruh nyata terhadap atribut tekstur cookies yang dihasilkan. Cookies memiliki tekstur yang mirip satu sama lain dikarenakan persentase tepung talas, jamur 
tiram, dan kuning telur yang digunakan dalam formula pembuatan cookies adalah sama yaitu sebesar $25 \%$ tepung talas, 25\% jamur tiram, dan 9\% kuning telur.

Menurut Millah dkk (2014), kerenyahan merupakan salah satu karakteristik yang penting pada produk makanan ringan, dimana konsumen akan menolak jika produk makanan ringan tersebut tidak renyah.Tekstur yang baik dipengaruhi oleh bahan dasar yang digunakan. Tekstur sebuah produk terutama cookies berhubungan dengan kadar air suatu produk tersebut. Kadar air yang tinggi membuat cookies tidak renyah dan teksturnya kurang disukai. Kadar lemak juga mempengaruhi tekstur dari cookies.

\section{d. Aroma}

Berdasarkan Tabel 13 menunjukan bahwa variasi formula 1 , formula 2 , dan formula 3 tidak berpengaruh nyata terhadap atribut aroma cookies yang dihasilkan.

Bumbu adalah suatu substansi tumbuhan aromatik yang telah dikeringkan dan biasanya sudah dalam bentuk bubuk (Rust, 1987). Bahan penyedap atau flavoring adalah zat atau komponen yang dapat memberikan rasa dan aroma tertentu pada bahan makanan sehingga sering ditambahkan pada bahan makanan (Asmorowati,2013). Bumbu serbuk masako membuat cookies memiliki aroma yang khas sehingga agak lebih disenangi panelis dibanding cookies dengan gula merah dan gula putih.

Aroma dalam industri pangan pengujiannya dianggap penting karena dengan cepat dalam memberikan hasil penilaian terhadap produk tentang diterima atau tidaknya produk tersebut dan merupakan indikator terjadinya kerusakan pada produk (Kartika,1988). Aroma yang khas dan bisa dirasakan oleh indera penciuman tergantung kepada bahan penyusun dan bahan yang ditambahahkan pada makanan tersebut. Sedangkan penilaian terhadap aroma dipengaruhi oleh psikis dan fisiologi yang memberikan pendapat berlainan (Kartika, 1988).

Formula terpilih dilihat dari taraf nyata setiap atribut organoleptik meliputi warna, rasa, tekstur, dan aroma. Formula 2 dengan formulasi gula pasir memiliki taraf nyata yang berbeda dengan formula 1 dan 3 dalam segi rasa. Sehingga formula 2 akan digunakan untuk penelitian utama.

\section{Hasil Penelitian Utama}

Penelitian utama dilakukan pembuatan cookies dengan formula yang terpilih pada penelitian pendahuluan dan dianalisis secara organoleptik dan kimia. Pada pengujian secara organoleptik dilakukan berdasarkan tingkat kesukaan panelis (hedonik) dengan atribut pengujian terhadap warna, rasa, tekstur, dan aroma. Sedangkan pada pengujian secara kimia dilakukan analisis kadar air menggunakan metode gravimetri, kadar protein menggunakan metode kjeldhal, kadar gula total menggunakan luff schoorls, dan kadar serat kasar menggunakan metode gravimetri.

\section{Uji Organoleptik}

Berdasarkan hasil analisis variasi menunjukan bahwa faktor perbandingan jamur dengan tepung talas berpengaruh terhadap warna, rasa, dan tekstur. Faktor konsentrasi kuning telur berpengaruh terhadap aroma. Faktor interaksi perbandingan jamur dengan tepung talas dan konsentrasi kuning telur berpengaruh terhadap warna dan rasa, secara keseluruhan dapat dilihat pada Tabel 14.

Tabel 2. Hasil Uji Organoleptik Cookies pada Penelitian Utama

\begin{tabular}{|l|l|l|l|l|}
\hline \multirow{2}{*}{ Perlakuan } & \multicolumn{4}{|c|}{ Respon Organoleptik } \\
\cline { 2 - 5 } & Warna & Rasa & Tekstur & Aroma \\
\hline t1s1 $(1: 2,6 \%)$ & $4,65 \mathrm{c}$ & $4,43 \mathrm{c}$ & $4,46 \mathrm{~b}$ & $4,03 \mathrm{a}$ \\
\hline t1s2 $(1: 2,9 \%)$ & $4,45 \mathrm{c}$ & $4,91 \mathrm{c}$ & $4,78 \mathrm{c}$ & $4,44 \mathrm{~b}$ \\
\hline t1s3 $(1: 2,12 \%)$ & $4,41 \mathrm{c}$ & $4,29 \mathrm{~b}$ & $4,77 \mathrm{c}$ & $4,12 \mathrm{a}$ \\
\hline t2s1 $(1: 1,6 \%)$ & $4,30 \mathrm{~b}$ & $4,22 \mathrm{a}$ & $4,15 \mathrm{a}$ & $4,21 \mathrm{a}$ \\
\hline t2s2 $(1: 1,9 \%)$ & $4,37 \mathrm{~b}$ & $4,78 \mathrm{~b}$ & $4,52 \mathrm{c}$ & $4,33 \mathrm{~b}$ \\
\hline t2s3 $(1: 1,12 \%)$ & $4,16 \mathrm{a}$ & $4,26 \mathrm{~b}$ & $4,77 \mathrm{c}$ & $4,15 \mathrm{a}$ \\
\hline t3s1 $(2: 1,6 \%)$ & $4,13 \mathrm{a}$ & $4,28 \mathrm{~b}$ & $3,74 \mathrm{a}$ & $4,30 \mathrm{a}$ \\
\hline t3s2 $(2: 1,9 \%)$ & $4,25 \mathrm{~b}$ & $3,72 \mathrm{a}$ & $4,00 \mathrm{~b}$ & $4,23 \mathrm{~b}$ \\
\hline t3s3 $(2: 1,12 \%)$ & $4,20 \mathrm{~b}$ & $3,70 \mathrm{a}$ & $4,25 \mathrm{a}$ & $4,21 \mathrm{a}$ \\
\hline
\end{tabular}

Keterangan : Nilai rata - rata yang diikuti huruf berbeda menunjukan perbedaan yang nyata pada uji lanjut Duncan taraf nyata 5\%. T merupakan perbandingan jamur dengan tepung talas dan $\mathrm{S}$ merupakan konsentrasi kuning telur.

\section{a. Warna}

Berdasarkan hasil penelitian, warna pada cookies dengan berbagai perlakuan diketahui bahwa pada analisis variansi (ANAVA) faktor perbandingan tepung talas dengan jamur (T) dan konsentrasi kuning telur (S) serta interaksinya berpengaruh nyata terhadap cookies yang dihasilkan. Pengaruh interaksi perbandingan tepung talas dengan jamur (T) dan konsentrasi kuning telur (S) terhadap cookies dapat dilihat pada Tabel 5.

Tabel 3. Pengaruh Interaksi Perbandingan Jamur dengan Tepung Talas dan Konsentrasi Kuning Telur terhadap Warna Cookies Talas Jamur (Faktor TS)

\begin{tabular}{|c|c|c|c|}
\hline \multirow{2}{*}{$\begin{array}{c}\text { Perbandingan Jamur : } \\
\text { Tepung Talas (T) }\end{array}$} & \multicolumn{3}{|c|}{ Konsentrasi Kuning Telur (S) } \\
\cline { 2 - 4 } & $6 \%$ & $9 \%$ & $12 \%$ \\
\hline$(1: 2)$ & $4,65 \mathrm{C}$ & $4,45 \mathrm{C}$ & $4,41 \mathrm{C}$ \\
& $\mathrm{b}$ & $\mathrm{b}$ & $\mathrm{A}$ \\
\hline$(1: 1)$ & $4,30 \mathrm{~B}$ & $4,37 \mathrm{~B}$ & $4,16 \mathrm{~A}$ \\
& $\mathrm{~b}$ & $\mathrm{c}$ & $\mathrm{a}$ \\
\hline & $4,13 \mathrm{~A}$ & $4,25 \mathrm{~A}$ & $4,20 \mathrm{~B}$ \\
& $\mathrm{a}$ & $\mathrm{c}$ & $\mathrm{b}$ \\
\hline
\end{tabular}

Keterangan : Nilai yang ditandai dengan huruf yang tidak sama menunjukan berbeda nyata pada taraf 5\% menurut uji Jarak Berganda Duncan. Notasi huruf besar dibaca vertical, notasi huruf kecil dibaca horizontal

Hasil penelitian utama pengujian organoleptik terhadap atribut warna cookies menunjukkan bahwa perbandingan jamur dengan tepung talas (1:2) didapatkan hasil yang berbeda nyata dibandingkan pada 
perbandingan jamur dengan tepung talas (1:1) dan (2:1), hal ini menunjukan bahwa perbandingan tepung talas yang lebih banyak memberikan pengaruh terhadap warna cookies sehingga lebih disenangi. Pada konsentrasi kuning telur $9 \%$ didapatkan hasil yang berbeda nyata dibandingkan pada konsentrasi kuning telur $12 \%$, hal ini menunjukan bahwa warna cookies tidak lagi disenangi apabila melebihi konsentrasi kuning telur $9 \%$.

Berdasarkan hasil pengamatan diperoleh kesimpulan bahwa semakin tinggi kadar protein maka warna cookies semakin coklat tua. Menurut Winarno (2004), warna bahan pangan dapat disebabkan oleh pigmen yang ada dalam bahan. Disamping itu, warna dapat ditmbulkan karena reaksi kimia antara gula pereduksi dan asam amino dari protein yang dikenal dengan reaksi browning non enzimatis atau reaksi mailard. Reaksi mailard terjadi akibat bereaksinya lisin dengan gula sederhana pada suhu tinggi. Bila gula pereduksi bereaksi dengan senyawa asam amino akan terbentuk hidroksi metil furaldehid jadi polimerisasi furfuraldehid membentuk melanoidin yang memberi warna coklat.

Menurut SNI, warna yang diperbolehkan untuk cookies adalah warna normal. Penambahan tepung talas menyebabkan warna cookies menjadi coklat. Selain itu kombinasi antara tepung talas dengan jamur dan kuning telur akan mempengaruhi terjadinya reaksi maillard karena tingginya protein yang bereaksi dengan karbohidrat pada tepung talas.

Warna merupakan suatu sifat bahan yang dianggap berasal dari penyebaran spectrum sinar, begitu juga sifat kilap dari bahan dipengaruhi oleh sinar terutama sinar pantul. Warna bukan merupakan suatu zat/benda melainkan suatu sensasi seseorang oleh karena adanya rangsangan dari seberkas energi radiasi yang jatuh ke indera mata/retina mata. Pengaruh sinar terlihat apabila suatu bahan dilihat ditempat yang suram dan ditempat yang gelap, akan memberikan perbedaan warna yang menyolok (Kartika,1988).

Warna seringkali sangat menentukan mutu dari produk pangan. Suatu produk pangan yang memiliki nilai gizi, rasa yang enak, dan memiliki bentuk yang menarik akan kurang diminati apabila memiliki warna yang tidak enak untuk dipandang atau memberi kesan telah menyimpang dari warna yang seharusnya (Winarno,1997).

b. Rasa

Berdasarkan hasil penelitian, rasa pada cookies dengan berbagai perlakuan diketahui bahwa pada analisis variansi (ANAVA) faktor perbandingan tepung talas dengan jamur (T) dan konsentrasi kuning telur (S) serta interaksinya berpengaruh nyata terhadap cookies yang dihasilkan. Pengaruh interaksi perbandingan tepung talas dengan jamur (T) dan konsentrasi kuning telur (S) terhadap cookies dapat dilihat pada Tabel 6.
Tabel 4. Pengaruh Interaksi antara Perbandingan Jamur dengan Tepung Talas dan Konsentrasi Kuning Telur terhadap Rasa Cookies Talas Jamur (Faktor TS)

\begin{tabular}{|c|c|c|c|}
\hline \multirow{2}{*}{$\begin{array}{c}\text { Perbandingan } \\
\text { Jamur : Tepung Talas }\end{array}$} & \multicolumn{3}{|c|}{ Konsentrasi Kuning } \\
\cline { 2 - 4 } & $6 \%$ & $9 \%$ & $12 \%$ \\
\hline \multirow{2}{*}{$(1: 2)$} & $4,43 \mathrm{C}$ & $4,91 \mathrm{C}$ & $4,29 \mathrm{~B}$ \\
$\mathrm{~b}$ & $\mathrm{c}$ & $\mathrm{a}$ \\
\hline$(1: 1)$ & $4,22 \mathrm{~A}$ & $4,78 \mathrm{~B}$ & $4,26 \mathrm{~B}$ \\
& $\mathrm{a}$ & $\mathrm{b}$ & $\mathrm{a}$ \\
\hline & $4,28 \mathrm{~B}$ & $3,72 \mathrm{~A}$ & $3,70 \mathrm{~A}$ \\
\hline & $\mathrm{b}$ & $\mathrm{a}$ & $\mathrm{a}$ \\
\hline
\end{tabular}

Keterangan : Nilai yang ditandai dengan huruf yang tidak sama menunjukan berbeda nyata pada taraf $5 \%$ menurut uji Jarak Berganda Duncan. Notasi huruf besar dibaca vertical, notasi huruf kecil dibaca horizontal

Hasil penelitian utama pengujian organoleptik terhadap atribut rasa cookies menunjukkan bahwa cookies dengan tepung talas yang lebih banyak lebih disukai, hal ini didukung dengan perbandingan jamur dengan tepung talas (1:2) berbeda nyata dibanding dengan perbandingan jamur dengan tepung talas (1:1) dan (2:1). Pada konsentrasi $12 \%$ berbeda nyata menunjukkan cookies masih disukai oleh panelis.

Rasa dinilai dengan adanya tanggapan rangsangan kimiawi oleh indera pencicip (lidah), dimana akhirnya keseluruhan interaksi antara sifat-sifat aroma, rasa, dan kerenyahan merupakan keseluruhan rasa makanan yang dinilai. Cita rasa juga dipengaruhi oleh tekstur, dari penelitian-penelitian diperoleh bahwa perubahan tekstur dapat mengubah rasa karena dapat mempengaruhi kecepatan timbulnya rangsangan terhadap sel reseptor olfaktori dan kelenjar air liur (Winarno,1997). Umumnya bahan pangan tidak hanya terdiri dari salah satu rasa, tetapi merupakan gabungan berbagai macam rasa secara terpadu sehingga menimbulkan cita rasa yang utuh. Bahan makanan mengandung $2 / 3$ atau 4 macam rasa, dasar pengaruh antara satu macam rasa dengan rasa yang lain tergantung pada konsentrasinya, bila salah satu komponen mempunyai konsentrasi yang lebih tinggi dari pada komponen yang lain maka komponen tersebut akan dominan. Bila perbedaan konsentrasi tidak terlalu besar maka kemungkinan timbul rasa gabungan/kompleks atau komponen-komponen tersebut dapat dirasakan kesemuanya secara berurutan (Kartika,1988).

c.Tekstur

Berdasarkan hasil penelitian, tekstur pada cookies dengan berbagai perlakuan diketahui bahwa pada analisis variansi (ANAVA) faktor perbandingan tepung talas dengan jamur (T) dan konsentrasi kuning telur (S) berpengaruh nyata terhadap cookies yang dihasilkan dapat dilihat pada Tabel 7 dan Tabel 8. 
Tabel 5. Pengaruh Perbandingan Jamur dengan Tepung Talas terhadap Tekstur Cookies Talas Jamur (Faktor T)

\begin{tabular}{|c|c|c|}
\hline Perbandingan Jamur:Tepung Talas & Nilai Rata-rata & Taraf nyata 5\% \\
\hline $\mathrm{t} 3(2: 1)$ & 4,00 & $\mathrm{a}$ \\
\hline $\mathrm{t} 1(1: 2)$ & 4,48 & $\mathrm{~b}$ \\
\hline $\mathrm{t} 2(1: 1)$ & 4,67 & $\mathrm{c}$ \\
\hline
\end{tabular}

Keterangan : Nilai rata-rata yang diikuti huruf berbeda, berbeda nyata menurut uji lanjut Duncan pada taraf 5\%.

Hasil penelitian utama pengujian organoleptik terhadap tekstur menunjukkan variasi perbandingan jamur dengan tepung talas (1:2), (1:1) dan (2:1) berbeda nyata. Perbandingan jamur dengan tepung talas (1:1) memiliki tekstur yang lebih disenangi karena dinilai memiliki tekstur yang lebih kokoh. Untuk konsentrasi kuning telur dapat dilihat pada Tabel 8.

Tabel 6. Pengaruh Konsentrasi Kuning Telur terhadap Tekstur Cookies Talas Jamur (Faktor S)

\begin{tabular}{|c|c|c|}
\hline Konsentrasi Kuning Telur & Nilai Rata-rata & Taraf nyata 5\% \\
\hline s1 $(6 \%)$ & 4,12 & $\mathrm{a}$ \\
\hline $\mathrm{s} 2(9 \%)$ & 4,43 & $\mathrm{~b}$ \\
\hline $\mathrm{s} 3(12 \%)$ & 4,60 & $\mathrm{c}$ \\
\hline
\end{tabular}

Keterangan : Nilai rata-rata yang diikuti huruf berbeda, berbeda nyata menurut uji lanjut Duncan pada taraf 5\%.

Hasil penelitian utama pengujian organoleptik terhadap tekstur menunjukkan variasi konsentrasi kuning telur $6 \%, 9 \%$ dan $12 \%$ berbeda nyata. Semakin tinggi konsentrasi kuning telur maka cookies semakin renyah dan disukai oleh panelis.

Tepung talas tidak memiliki gluten yang berperan terhadap pembentukan tekstur cookies Ketergnganik, sedangkan tepung terigu mengandung protein gluten. Semakin tinggi kandungan protein gluten pada tepung terigu, cookies yang dihasilkan memiliki tingkat kerenyahan paling baik dan sebaliknya (Ariantya, 2016). Tepung talas berfungsi sebagai kerangka cookies sedangkan untuk kerenyahannya menggunakan kuning telur yang bertindak sebagai emulsifier. Perbandingan tepung talas dengan jamur (1:1) dinilai memiliki tekstur yang lebih baik karena memiliki perbandingan yang seimbang. Kandungan jamur yang tinggi menyebabkan cookies lembek karena kadar airnya yang tinggi. Sedangkan kandungan tepung talas yang tinggi menyebabkan cookies lembut dan aagak rapuh karena kadar amilopektinnya yang tinggi.

Penambahan kuning telur dapat mempengaruhi tekstur cookies. Lesitin pada kuning telur merupakan emulsifier yang memiliki kemampuan untuk berikatan dengan air maupun lemak, karena terdapat ikatan hidrofil dan hidrofob (Basuki,2013). Protein akan mengalami koagulasi apabila dipanaskan pada suhu $50^{\circ} \mathrm{C}$ atau lebih. Penggumpalan protein biasanya didahului oleh proses denaturasi yang berlangsung dengan baik pada titik isoelektrik protein tersebut (Poedjiadi dan
Supriyanti,2005). Koagulasi menyebabkan terbentuknya ikatan antar molekul protein yang memperkokoh tekstur (Basuki,2013).

Tekstur merupakan sensasi tekanan yang dapat diamati dengan mulut (pada waktu digigit, dikunyah, dan ditelan) ataupun perabaan dengan jari. Pada saat dilakukan pengujian inderawi, sifat-sifat seperti keras atau lemahnya bahan pada saat digigit, pemecahan dalam fragmen-fragmen, hubungan antar serat-serat yang ada, dan sensasi lain misalnya berminyak, rasa berair, rasa mengandung cairan dan lain-lain kemungkinan akan timbul. Dapat juga pengamatan dengan jari akan menimbulkan kesan apakah sesuatu bahan mudah pecah atau remuk (Kartika,1988).

Tekstur merupakan atribut produk yang cukup penting dalam cookies sebab biasanya cookies dinilai dari teksturnya.Tekstur pada cookies meliputi kekerasan, kemudahan dipatahkan, dan konsistensi pada gigitan pertamanya. Tekstur dipengaruhi oleh bahan yang digunakan dalam membuat produk (Fellows, 2000).

Aroma

Berdasarkan hasil penelitian, aroma pada cookies dengan berbagai perlakuan diketahui bahwa pada analisis variansi (ANAVA) faktor konsentrasi kuning telur (S) terhadap cookies, dapat dilihat pada Tabel 9.

Tabel 7. Pengaruh Konsentrasi Kuning Telur Terhadap Aroma Cookies Talas Jamur (Faktor S)

\begin{tabular}{|c|c|c|}
\hline Konsentrasi Kuning Telur & $\begin{array}{c}\text { Nilai } \\
\text { Rata-rata }\end{array}$ & $\begin{array}{c}\text { Taraf } \\
\text { nyata } \\
5 \%\end{array}$ \\
\hline s3 (12\%) & 4,16 & $\mathrm{a}$ \\
\hline s1 (6\%) & 4,18 & $\mathrm{a}$ \\
\hline s2 (9\%) & 4,34 & $\mathrm{~b}$ \\
\hline
\end{tabular}

Keterangan : Nilai rata-rata yang diikuti huruf berbeda, berbeda nyata menurut uji lanjut Duncan pada taraf 5\%.

Hasil penelitian utama pengujian organoleptik terhadap aroma menunjukkan variasi konsentrasi kuning telur, konsentrasi kuning telur $9 \%$ berbeda nyata dengan $6 \%$ dan $12 \%$. Untuk perbandingan jamur dan tepung talas tidak berbeda nyata terhadap aroma talas jamur.

Cookies dengan menggunakan konsentrasi kuning telur $9 \%$ dinilai memiliki aroma yang lebih baik dibanding dengan konsentrasi $6 \%$ dan $12 \%$. Cookies dengan konsentrasi $6 \%$ tidak terlalu memiliki aroma yang signifikan. Sedangkan cookies dengan konsentrasi $12 \%$ memiliki aroma yang terlalu menyengat.

Aroma (bau-bauan) dapat didefinisikan sebagai sesuatu yang dapat diamati dengan indera pembau. Untuk dapat menghasilkan aroma, zat-zat aroma harus dapat menguap, sedikit larut dalam air, dan sedikit dapat larut dalam lemak. Dalam industri pangan pengujian terhadap aroma dianggap penting karena dengan cepat dapat memberikan hasil penilaian terhadap produk diterima atau tidaknya produk tersebut. Selain itu aroma dapat dipakai sebagai indikator terjadinya kerusakan pada produk (Kartika, 1988). 
Aroma suatu bahan pangan merupakan fungsi dari kandungan bahan yang dimilikinya. Aroma bahan pangan dapat menentukan kelezatan suatu bahan pangan. Dalam hal ini aroma dipengaruhi oleh alat panca indera pencium (hidung). Pada umumnya aroma yang diterima oleh hidung dan otak lebih banyak merupakan campuran dari empat aroma yaitu harum, asam, tengik, dan hangus (Winarno,1997).

Aroma yang dikeluarkan oleh bahan pangan dapat menunjukan kualitas dari bahan pangan tersebut dan menunjukan enak tidaknya suatu bahan pangan. Aroma yang dikeluarkan oleh bahan pangan akan tercium oleh sel epithelium olfaktori yang terdapat pada rongga hidung bagian atas. Aroma-aroma dihasilkan dari interaksi zat-zat yang ada dalam bahan pangan dengan sel epithelium olfaktori tersebut (Soekarto,1985).

\section{Kadar Air}

Berdasarkan hasil penelitian, kadar air pada cookies dengan berbagai perlakuan diketahui bahwa pada analisis variansi (ANAVA) faktor perbandingan tepung talas dengan jamur (T) berpengaruh nyata terhadap cookies yang dihasilkan, dapat dilihat pada Tabel 10.

Tabel 8. Pengaruh Perbandingan Jamur dengan Tepung Talas terhadap Kadar Air Cookies Talas Jamur (Faktor T)

\begin{tabular}{|c|c|c|}
\hline $\begin{array}{c}\text { Perbandingan } \\
\text { Jamur:Tepung Talas }\end{array}$ & $\begin{array}{c}\text { Nilai Rata- } \\
\text { rata }\end{array}$ & $\begin{array}{c}\text { Taraf nyata } \\
5 \%\end{array}$ \\
\hline $\mathrm{t} 1(1: 2)$ & 2,48 & $\mathrm{a}$ \\
\hline $\mathrm{t} 2(1: 1)$ & 3,88 & $\mathrm{~b}$ \\
\hline $\mathrm{t} 3(2: 1)$ & 4,54 & $\mathrm{~b}$ \\
\hline
\end{tabular}

Keterangan : Nilai rata-rata yang diikuti huruf berbeda, berbeda nyata menurut uji lanjut Duncan pada taraf 5\%.

Hasil penelitian utama pengujian kimia terhadap kadar air menunjukkan variasi perbandingan jamur dengan tepung talas. Perbandingan jamur dengan tepung talas (2:1) dan (1:1) berbeda nyata dengan (1:2). Untuk konsentrasi kuning telur tidak berbeda nyata terhadap kadar air cookies talas jamur.

Rata-rata kadar air yang memenuhi syarat SNI cookies adalah pada perbandingan jamur dengan tepung talas (1:2) dan (1:1), hal ini dikarenakan konsentrasi tepung talas lebih besar atau sama dari konsentrasi jamur. Syarat kadar air pada SNI cookies yaitu maksimal $4 \%$. Jamur memiliki kadar air yang tinggi yaitu sekitar 73,790,8\% per 100 gram berat bahan (Hasan, 2013). Pada jamur tidak dilakukan perlakuan pendahuluan pembuatan tepung jamur karena memiliki rendemen yang kecil. Oleh karena itu, cookies dengan kandungan jamur yang tinggi memiliki kadar air yang tinggi.

Kadar air merupakan jumlah air yang terkandung dalam bahan pangan secara total dan biasanya dinyatakan dalam persen berat bahan pangan tersebut (Kartini,2006). Kadar air bahan sangat berpengaruh terhadap zat atau materi atau unsur yang penting bagi semua bentuk kehidupan yang diketahui sampai saat ini di bumi, tetapi tidak di planet lain. Kadar air diperlukan untuk kelangsungan proses biokimiawi organisme hidup, sehingga sangat esensial dalam menentukan kandungan kadar air pada bahan pangan (Ahmadi dan Estiasih,2009).

\section{Kadar Protein}

Berdasarkan hasil penelitian, kadar protein pada cookies dengan berbagai perlakuan diketahui bahwa pada analisis variansi (ANAVA) faktor perbandingan tepung talas dengan jamur (T) berpengaruh nyata terhadap cookies yang dihasilkan, dapat dilihat pada Tabel 11 .

Tabel 9. Pengaruh Perbandingan Jamur dengan Tepung Talas terhadap Kadar Protein Cookies Talas Jamur (Faktor T)

\begin{tabular}{|c|c|c|}
\hline Perbandingan Jamur:Tepung Talas & Nilai Rata-rata & Taraf nyata 5\% \\
\hline t1 (1:2) & 25,08 & $\mathrm{a}$ \\
\hline $\mathrm{t} 2(1: 1)$ & 25,35 & $\mathrm{a}$ \\
\hline $\mathrm{t} 3(2: 1)$ & 26,65 & $\mathrm{~b}$ \\
\hline
\end{tabular}

Keterangan : Nilai rata-rata yang diikuti huruf berbeda, berbeda nyata menurut uji lanjut Duncan pada taraf $5 \%$.

Hasil penelitian utama pengujian kimia terhadap kadar protein menunjukkan variasi perbandingan jamur dengan tepung talas. Perbandingan jamur dengan tepung talas $(2: 1)$ berbeda nyata dengan $(1: 1)$ dan $(1: 2)$. Untuk konsentrasi kuning telur tidak berbeda nyata terhadap kadar protein cookies talas jamur.

Rata-rata kadar protein seluruh perlakuan memenuhi syarat SNI cookies yaitu minimal $6 \%$. Kenaikan kadar protein pada cookies disebabkan karena kandungan protein dalam jamur tiram cukup tinggi yaitu sebesar 27,25. Tepung talas memiliki kandungan protein sebesar 6,43 dan kuning telur memiliki kandungan protein sebesar 15,7-16,6.

Jamur tiram memiliki kandungan protein yang lebih tinggi daripada sayuran lainnya ataupun daging sapi. Protein dalam jamur mengandung asam amino esensial. Asam amino esensial adalah asam amino yang sangat dibutuhkan tubuh dalam jumlah cukup, tetapi tidak dapat dihasilkan oleh tubuh. Terdapat sembilan asam amino esensial pada jamur, yaitu lisin, methionine, triptofan, threonine, valin, leusin, isoleusin, histidin, dan fenilalanin (Achmad,2013).

Kadar protein yang dihasilkan dalam penelitian ini tidak berbeda jauh dengan hasil penelitian yang dilakukan oleh Eka (2013), yang menunjukan kadar protein pada kerupuk udang rebon dengan penambahan jamur tiram dalam keadaan mentah sebesar $18,05 \%$ dan dalam keadaan matang sebesar $16,92 \%$. Penurunan ini dikarenakan dari pemasakan sehingga kandungan protein kerupuk udang rebon dalam keadaan mentah lebih banyak daripada keadaan matang, dikarenakan kandungan protein turun pada proses penggorengan sehingga mengakibatkan denaturasi.

Perlakuan panas dapat memberikan pengaruh yang menguntungkan dan merugikan terhadap protein. 
Pengaruh yang menguntungkan yaitu meningkatkan daya guna protein, sebab adanya pemanasan pada proses pengolahan dapat menginaktifkan atau menurunkan protein inhibitor. Sedangkan pengaruh yang merugikan adalah terjadinya denaturasi protein (Winarno, 1997).

Pengaruh pengeringan (panas) menyebabkan terdenaturasinya protein yang terkandung dalam produk pangan sehingga mengakibatkan berkurangnya kadar protein seiring dengan perbedaan lama pengeringannya. Kadar protein mudah sekali mengalami perubahan (Sudarmadji,2007).

Denaturasi dapat diartikan suatu perubahan atau modifikasi terhadap struktur sekunder, tersier, dan kuartener terhadap molekul protein, tanpa terjadi pemecahan ikatan-ikatan kovalen. Karena itu denaturasi dapat pula diartikan sebagai suatu proses terpecahnya ikatan-ikatan hidrogen, interaksi hidrofobik, ikatan garam, dan terbukanya lipatan atau penumpukan molekul (Winarno, 1997).

\section{Kadar Serat Kasar}

Berdasarkan hasil penelitian, kadar serat kasar pada cookies dengan berbagai perlakuan diketahui bahwa pada analisis variansi (ANAVA) faktor perbandingan tepung talas dengan jamur $(\mathrm{T})$ berpengaruh nyata terhadap cookies yang dihasilkan, dapat dilihat pada Tabel 22.

Tabel 10. Pengaruh Perbandingan Jamur dengan Tepung Talas terhadap Kadar Serat Kasar Cookies Talas Jamur (Faktor T)

\begin{tabular}{|c|c|c|}
\hline $\begin{array}{c}\text { Perbandingan } \\
\text { Jamur:Tepung Talas }\end{array}$ & $\begin{array}{c}\text { Nilai Rata- } \\
\text { rata }\end{array}$ & $\begin{array}{c}\text { Taraf nyata } \\
5 \%\end{array}$ \\
\hline $\mathrm{t} 1(1: 2)$ & 2,26 & $\mathrm{a}$ \\
\hline $\mathrm{t} 2(1: 1)$ & 2,67 & $\mathrm{~b}$ \\
\hline $\mathrm{t} 3(2: 1)$ & 2,83 & $\mathrm{~b}$ \\
\hline
\end{tabular}

Keterangan: Nilai rata-rata yang diikuti huruf berbeda, berbeda nyata menurut uji lanjut Duncan pada taraf 5\%

Hasil penelitian utama pengujian kimia terhadap kadar serat menunjukkan variasi perbandingan jamur dengan tepung talas. Perbandingan jamur dengan tepung talas $(2: 1)$ dan $(1: 1)$ berbeda nyata dengan $(1: 2)$. Untuk konsentrasi kuning telur tidak berbeda nyata terhadap kadar serat kasar cookies talas jamur.

Kadar serat kasar yang tinggi dipengaruhi oleh konsentrasi jamur tiram, semakin tinggi konsentrasi jamur tiram maka semakin tinggi kadar serat kasarnya. Berdasarkan taraf nyata, perbandingan jamur dengan tepung talas (2:1) berbeda nyata dengan (1:2) dan (1:1) disebabkan jamur memiliki serat yang tinggi yaitu 33,4 gram per 100 gram berat bahan sedangkan pada talas 0,7 gram per 100 gram berat bahan.

Rata-rata kadar serat kasar tidak ada yang memenuhi syarat SNI cookies pada perbandingan jamur dengan tepung talas $(1: 2),(1: 1)$, dan $(2: 1)$. Syarat SNI serat kasar pada cookies yaitu maksimal $0,5 \%$. Hal ini diduga terjadi karena penggunaan jamur tiram berupa sayuran segar, yang mengandung banyak serat alami sehingga jumlah serat kasarnya lebih banyak. Berbeda dengan cookies pada umumnya yang menggunakan bahan tambahan berupa tepung-tepungan.

Kadar serat kasar yang dihasilkan dalam penelitian ini tidak berbeda jauh dengan hasil penelitian yang dilakukan oleh Suprihana (2010), yang menunjukan kadar serat kasar pada flakes jamur tiram berkisar antara $2,168 \%$. Semakin tinggi proporsi tepung jamur tiram yang digunakan, kadar serat kasar flakes akan semakin meningkat dan semakin lama waktu pengukusan, menunjukan kadar serat flakes akan menurun.

Dua macam golongan serat yaitu serat yang tidak dapat larut dalam air dan serat yang dapat larut air. Serat yang tidak dapat larut dalam air adalah selulosa, hemiselulosa, dan lignin. Serat yang dapat larut air adalah pectin, gum, glikan, dan alga yang cenderung bercampur dengan air membentuk gel (seperti agar) atau jaringan yang pekat (Suwetja, 2011)

Serat kasar adalah senyawa yang biasa dianalisa di laboratorium yaitu senyawa yang tidak dapat dihidrolisa oleh asam atau alkali. Serat kasar adalah serat tumbuhan yang larut dalam air. Kadar serat dalam suatu makanan dapat dijadikan indeks kadar serat makanan karena umumnya di dalam serat kasar ditemukan sebanyak 0,2 sampai dengan 0,5 bagian jumlah serat makanan (Winarno, 1997).

Serat kasar merupakan bagian dari serat pangan yang tidak larut di dalam air. Serat pangan adalah makanan yang berbentuk karbohidrat kompleks yang banyak terdapat pada dinding sel tanaman pangan. Serat pangan tidak dapat dicerna dan tidak diserap oleh saluran pencernaan manusia, tetapi memiliki fungsi yang sangat penting bagi pemeliharaan kesehatan, pencegahan penyakit, dan sebagai komponen penting dalam terapi gizi (Astawan, 2004).

Serat diperlukan dalam membantu mempercepat sisa makanan melalui saluran pencernaan untuk diekskresikan keluar. Serat kasar menjadi seperti karet busa di dalam usus yang akan menyerap zat buangan dan membantu gerakan peristaltik usus mendorong sisa makanan keluar tubuh. Serat kasar sangat penting dalam pencegahan disfungsi alat pencernnaan seperti konstipasi, wasir, kanker usus besar dan infeksi usus buntu. Serat kasar juga menghambat lewatnya glukosa melalui dinding saluran pencernaan menuju pembuluh darah (Ariantya, 2016).

\section{Kadar Gula Total}

Berdasarkan hasil penelitian, kadar gula total pada cookies dengan berbagai perlakuan diketahui bahwa pada analisis variansi (ANAVA) faktor perbandingan tepung talas dengan jamur (T) berpengaruh nyata terhadap cookies yang dihasilkan, dapat dilihat pada Tabel 13 
Tabel 11. Pengaruh Perbandingan Jamur dengan Tepung Talas terhadap Kadar Gula Total Cookies Talas Jamur (Faktor T)

\begin{tabular}{|c|c|c|}
\hline $\begin{array}{c}\text { Perbandingan } \\
\text { Jamur:Tepung Talas }\end{array}$ & $\begin{array}{c}\text { Nilai } \\
\text { Rata- } \\
\text { rata }\end{array}$ & $\begin{array}{c}\text { Taraf } \\
\text { nyata } \\
5 \%\end{array}$ \\
\hline $\mathrm{t} 3(2: 1)$ & 55,16 & $\mathrm{a}$ \\
\hline $\mathrm{t} 2(1: 1)$ & 64,05 & $\mathrm{ab}$ \\
\hline $\mathrm{t} 1(1: 2)$ & 71,46 & $\mathrm{~b}$ \\
\hline
\end{tabular}

Keterangan : $\quad$ Nilai rata-rata yang diikuti huruf berbeda, berbeda nyata menurut uji lanjut Duncan pada taraf $5 \%$.

Hasil penelitian utama pengujian kimia terhadap kadar gula total menunjukkan variasi perbandingan jamur dengan tepung talas. Perbandingan jamur dengan tepung talas (1:2) berbeda nyata dengan $(2: 1)$ dan perbandingan jamur dengan tepung talas (1:1) tidak berbeda nyata dengan (1:2) dan (2:1). Untuk konsentrasi kuning telur tidak berbeda nyata terhadap kadar gula total cookies talas jamur.

Rata-rata kadar gula total yang memenuhi syarat SNI cookies adalah pada perbandingan jamur dengan tepung talas (1:2), hal ini dikarenakan konsentrasi tepung talas lebih besar. Berdasarkan hasil penelitian kadar gula total dipengaruhi tepung talas, semakin tinggi kandungan tepung talas maka semakin tinggi kadar gula total pada cookies. Syarat kadar gula total pada SNI cookies yaitu minimal $70 \%$.

Gula total merupakan campuran gula reduksi dan non reduksi yang merupakan hasil hidrolisa pati. Menurut Setiawan (2006), Gula total menunjukkan jumlah karbohidrat yang terkandung dalam hidrolisat. Hasil pemotongan rantai molekul pati oleh $\alpha$-amilase mengakibatkan jumlah molekul oligosakarida meningkat. Jumlah gula-gula pereduksi maupun non-pereduksi dari oligosakarida akan bertambah dan terbaca sebagai gula total. Ketika pati dihidrolisis, makromolekulnya akan terdegradasi menjadi molekul-molekul yeng lebih kecil dengan rantai lebih pendek.

Talas mengandung karbohidrat berkisar antara 13-29\% dengan komponen utama adalah pati yang mencapai 77,9\% (Onwueme,1994). Karbohidrat pada umbi talas sebagian besar merupakan komponen pati, sedangkan komponen lainnya pentosa, serat kasar, dekstrin, sukrosa, dan gula pereduksi. Pati talas mengandung 17-28\% amilosa, dan sisanya adalah amilopektin. Amilosa memiliki 490 unit glikosa per molekul dan amilopektin memiliki 22 unit glukosa per molekul. Talas mempunyai granula pati sangat kecil yaitu berkisar 3-4 $\mu \mathrm{m}$. Komposisi pati talas dipengaruhi oleh varietas iklim, kesuburan tanah, umur panen, dll. (Richana, 2012).

Karbohidrat dalam jamur terdapat dalam bentuk molekul pentose, metilpentosa, dan heksosa. Karbohidrat terbesar pada jamur berada dalam bentuk heksosan dan pentosan. Polimer karbohidrat dapat berupa glikogen, kitin, dan sebuah polimer $\mathrm{N}$-asetil glikosamin yang merupakan komponen structural sel jamur. Jamur juga mampu mengubah selulosa menjadi polisakarida yang bebas kolesterol sehingga orang mengkonsumsinya terhindar dari resiko terkena stroke (Achmad,2013).

Produk terpilih dilihat dari setiap parameter yang ada yaitu respon organoleptik meliputi warna, rasa, tekstur, dan aroma. Produk terpilih diambil berdasarkan taraf nyata dan nilai rata-rata terbesar dari atribut yang diujikan. Respon kimia dilihat berdasarkan kesesuaian SNI (Standar Nasional Indonesia) mengenai cookies. Berdasarkan respon organoleptik, produk variasi perbandingan jamur dengan tepung talas (1:2) dengan konsentrasi kuning telur $9 \%$. Hal tersebut dapat dilihat pada Tabel 14

Tabel 12. Penentuan Sampel Cookies Talas Jamur Terbaik

\begin{tabular}{|l|c|c|c|c|}
\hline \multirow{2}{*}{ Perlakuan } & \multicolumn{5}{|c|}{ Respon Organoleptik } \\
\cline { 2 - 5 } & Warna & Rasa & Tekstur & Aroma \\
\hline t1s1 $(1: 2,6 \%)$ & $4,65 \mathrm{c}$ & $4,43 \mathrm{c}$ & $4,46 \mathrm{~b}$ & $4,03 \mathrm{a}$ \\
\hline $\mathrm{t} 1 \mathrm{~s} 2(1: 2,9 \%)$ & $4,45 \mathrm{c}$ & $4,91 \mathrm{c}$ & $4,78 \mathrm{c}$ & $4,44 \mathrm{~b}$ \\
\hline $\mathrm{t} 1 \mathrm{~s} 3(1: 2,12 \%)$ & $4,41 \mathrm{c}$ & $4,29 \mathrm{~b}$ & $4,77 \mathrm{c}$ & $4,12 \mathrm{a}$ \\
\hline $\mathrm{t} 2 \mathrm{~s} 1(1: 1,6 \%)$ & $4,30 \mathrm{~b}$ & $4,22 \mathrm{a}$ & $4,15 \mathrm{a}$ & $4,21 \mathrm{a}$ \\
\hline $\mathrm{t} 2 \mathrm{~s} 2(1: 1,9 \%)$ & $4,37 \mathrm{~b}$ & $4,78 \mathrm{~b}$ & $4,52 \mathrm{c}$ & $4,33 \mathrm{~b}$ \\
\hline $\mathrm{t} 2 \mathrm{~s} 3(1: 1,12 \%)$ & $4,16 \mathrm{a}$ & $4,26 \mathrm{~b}$ & $4,77 \mathrm{c}$ & $4,15 \mathrm{a}$ \\
\hline t3s1 (2:1,6\%) & $4,13 \mathrm{a}$ & $4,28 \mathrm{~b}$ & $3,74 \mathrm{a}$ & $4,30 \mathrm{a}$ \\
\hline t3s2 (2:1,9\%) & $4,25 \mathrm{~b}$ & $3,72 \mathrm{a}$ & $4,00 \mathrm{~b}$ & $4,23 \mathrm{~b}$ \\
\hline t3s3 (2:1, 12\%) & $4,20 \mathrm{~b}$ & $3,70 \mathrm{a}$ & $4,25 \mathrm{a}$ & $4,21 \mathrm{a}$ \\
\hline Keterangan : Nilai rata - rata yang diikuti huruf berbeda menunjukan \\
perbedaan yang nyata pada uji lanjut Duncan taraf nyata \\
5\%.
\end{tabular}

Berdasarkan uji organoleptik sampel dengan perlakuan t1s2 memiliki respon organoleptik rasa, tekstur, dan aroma yang paling disukai oleh panelis. Sampel ini juga memiliki kandungan kadar air sebesar 2,48\%, kadar protein $25,08 \%$, dan kadar karbohidrat $71,46 \%$ yang sesuai dengan SNI cookies. Sedangankan untuk kadar serat memiliki kandungan sebesar 2,26\% yang melebihi dari syarat SNI.

Berdasarkan hasil penelitian, dapat diambil kesimpulan sebagai berikut :

1. Berdasarkan hasil penelitian pendahuluan dipilih perlakuan F2 (formulasi 2 dengan formula menggunakan gula pasir).

2. Perbandingan jamur dengan tepung talas (T) berpengaruh terhadap warna, rasa, tekstur dan respon kimia, tetapi tidak berpengaruh terhadap aroma cookies talas jamur.

3. Konsentrasi kuning telur (S) berpengaruh terhadap warna, rasa, tekstur dan aroma, tetapi tidak berpengaruh pada respon kimia cookies talas jamur.

4. Interaksi antara perbandingan jamur dengan tepung talas (T) dan konsentrasi kuning telur (S) berpengaruh terhadap warna dan rasa, tetapi tidak berpengaruh terhadap tekstur, aroma, dan respon kimia cookies talas jamur.

5. Perlakuan terpilih berdasarkan respon organoleptik dan kimia adalah t1s2 (perbandingan jamur dengan tepung talas (1:2) dan konsentrasi kuning telur 6\%), dengan kandungan kadar air sebesar 2,48\%, kadar protein $25,08 \%$, kadar serat sebesar 2,26\% dan kadar karbohidrat $71,46 \%$. 


\section{Daftar Pustaka}

1. Achmad. 2013. Murraya Paniculata (L.) Jack. (Rutaceae) Ilmu Kimia dan Kegunaan Tumbuhtumbuhan Obat Indonesia. Penerbit Institut Teknologi Bandung, Bandung.

2. Aditya, R. dan D. Saraswati. 2012. 10 Jurus Sukses Beragribisnis Jamur. Penebar Swadaya, Jakarta.

3. Afriananda, R. 2011. Pengaruh Penambahan Sukrosa dan Glukosa pada Pembuatan Permen Karamel Susu Kambing terhadap Sifat Kimia, Mikrobiologi dan Organoleptik. Skripsi : Fakultas Pertanian Universitas Lampung.

4. Ahmadi dan T. Estiasih. 2009. Teknologi Pengolahan Pangan. Bumi Aksara, Jakarta.

5. Aj-Juwita, A.T. dan J. Kusnadi. 2015. Pembuatan Biskuit Beras Parboiled (Kajian Proporsi Tepung Beras Parboiled dengan Tepung Tapioka dan Penambahan Kuning Telur). Jurnal Pangan dan Agroindustri Vol.3 No.4.

6. Alex, M. 2011. Untung Besar Budi Daya Aneka Jamur. Pustaka Baru Press, Yogyakarta.

7. Ananto, D.S. 2009. Buku Pintar Membuat Kue Kering. PT. Agromedia Pustaka, Jakarta

8. Anjarsari, B. 2010. Pangan Hewani Fisiologi Pasca Mortem dan Teknologi, Graha Ilmu, Yogyakarta.

9. Anwar, Y. 2012. Untung Menggunung dari Bisnis Olahan Jamur. PT. Agromedia Pustaka, Jakarta.

10. Apriadji, W.H. 2007. Good Mood Food. PT Gramedia Pustaka Utama, Jakarta.

11. Apriyani, R. N. N., Setyadit, dan M. Arpah. 2011. Karakterisasi Empat Jenis Umbi Talas Varian Mentega, Hijau, Semir, dan Beneng serta Tepung yang Dihasilkan dari Keempat Varian Umbi Talas. Jurnal Ilmu Pangan Vol.1 No.1.

12. Ariantya, F.S. 2016. Kualitas Cookies dengan Kombinasi Tepung Terigu, Pati batang Aren (Arenga pinnata) dan Tepung Jatung Pisang (Musa paradisiaca). Jurnal : Universitas Atmajaya Yogyakarta.

13. Astawan, M. 2004. Tetap Sehat dengan Produk makanan Olahan. Tiga Serangkai, Surakarta.

14. Asmorowati, D.A. 2013. Bahan Penyedap Makanan atau Food Flavor. Makalah: Fakultas Teknologi pertanian Universitas Brawijaya.

15. Azizah, N.A., T. Widiantara, dan Sumartini. 2014. Kajian Perbandingan Tepung Mocaf (Modified Cassava Flour) yang Disubsitusi Tepung Kacang Koro Pedang dan Lama Pemanggangan dalam Pembuatan Cookies. Jurnal Ilmu Pangan.

16. Buckle, K.A., R.A. Edwards, G.H. Fleet, dan M. Wootton. 2007. Ilmu Pangan. Penerbit UI Press, Jakarta.

17. Chazali, S. dan P. Pratiwi. 2010. Usaha jamur Tiram Skala Rumah Tangga. Swadaya, Jakarta.

18. Daniel, A.R. 1978. Bakery Materials and Method. Applied Science Publishers LTD, England.

19. Ermayuli. 2011. Analisis Teknis dan Finansial Agroindustri Skala Kecil pada berbagai Proses
Pembuatan Keripik Talas di Kabupaten Lampung Barat. Skripsi : Fakultas Pertanian Universitas Lampung.

20. Fatkurahman, R., W. Atmaka, dan Basito. 2012. Karakteristk Sensoris dan Sifat Fisikokimia Cookies dengan Substitusi Bekatul Beras Hitam (Oryza sativa L.) dan Tepung Jagung (Zea Mays L.). Jurnal Teknosains Pangan Vol 1 No 1.

21. Fatmawati, W.T. 2012. Pemanfaatan Tepung Sukun Dalam Pembuatan Produk Cookies. UNYPress, Yogyakarta.

22. Fellows, P.J. 2000. Food Processing Technology, Principle and Practice. Published by Ellis Horwood Limitted, England.

23. Gaspersz, V. 1995. Metode Rancangan Percobaan Edisi Kedua. Penerbit CV Armico, Bandung.

24. Hartati, N.S. dan T. K. Prana. 2003. Analisis Kadar Pati dan Serat Kasar Tepung Beberapa Kultivar Talas (Colocasia esculenta L. Schott). Jurnal Natur Indonesia Vol 6 No.1

25. Hasan, M. 2013. Kandungan Gizi Jamur Tiram. www.bbpp-lembang.info. Diakses: 10/08/2016.

26. Hastuti, A. Y. 2012. Aneka Cookies Paling Favorit, Populer, Istimewa. Cetakan Pertama. Dunia Kreasi, Jakarta.

27. Heldman, D. R. dan Lund, D. B. 2007. Handbook of Food Engeneering. Edisi ke 2. CRC-Press, USA.

28. Hubeis, M. 1984. Pengantar Pengelolaan Tepung Serealia dan Biji-bijian. IPB-Press, Bogor.

29. Julianto. 2014. Bioindustri Talas Cukup Prospektif. Iptek, Teknologi. Tabloid Sinar Tani, Bogor.

30. Kartika, B., P. Harstuti, dan W. Supartona. 1988. Pedoman Uji Inderawi Bahan Pangan. Pusat Antar Universitas Pangan dan Gizi, Yogyakarta.

31. Kartini, I. 2006. Pengaruh Lama Pengeringan dan Variasi Perbandingan Formula Terhadap Karakteristik Kerupuk Tiras. Skripsi : Jurusan Teknologi Pangan Universitas Pasundan, Bandung.

32. Koswara, S. 2013. Teknologi Pengolahan Umbiumbian. http://seafast.ipb.ac.id. Diakses: 10/08/2016.

33. Kusnandar, F. 2010. Kimia Pangan, Komponen Pangan. PT Dian Rakyat, Jakarta.

34. Lestari, N, W. Syarif, dan R. Holinesti. 2015. Pengaruh Substitusi Tepung Talas Terhadap Kualitas Cookies. Skripsi : Fakultas Teknik Universitas Negeri Padang.

35. Lingga P., B. Sarwono, F.Rahardi. P. C. Rahardja, J. J. Afriastini, R. Wudianto, dan W. H. Apriadji. 1990. Bertanam Umbi-umbian. PT Penebar Swadaya, Jakarta.

36. Lopulalan, C.G.C., M. Mailoa, dan D.R. Sangadji. 2013. Kajian Formulasi Penambahan Tepung Ampas Tahu Terhadap Sifat Organoleptik dan Kimia Cookies. Jurnal Agritekno Vol.2 No.1.

37. Meinanda, I., 2013. Panen Cepat Budidaya Jamur. Padi, Bandung. 
38. Millah, I.I.I., Wignyanto, dan Ika. 2014. Pembuatan Cookies (Kuekering) dengan Kajian Penambahan Apel Manalagi (Mallus sylvestris Mill) Subgrade dan Margarin. Jurnal Teknologi Industri Pertanian.

39. Mohamed, S., dan Hussein, R. 1994. Effect of Low Temperature Blanching, Cysteine-HCl, N-acetylL-Cysteine, Na-Metabisulphit and Drying Temperature on the Firmness and Nutrient Content of Dried Carrots. Journal Food Proc. And Pres. 18:343-348

40. Muchtadi, T.R, Sugiyono, dan F. Ayustaningwarno. 2013. Ilmu Pengetahuan Bahan Pangan. Alfabeta, Bandung.

41. Mudita, I.W. 2012. http://tanamankampung.blogspot.co.id.

Talas. 10/08/2016.

42. Mudjajanto, E dan L. Yuliani. 2004. Membuat Kue. Penebar Swadaya, Jakarta.

43. Mutiara, E., Adikahriani, dan S. Wahidah. 2012. Pengembangan Formula Biskuit Daun Katuk Untuk Meningkatkan Produksi Asi. Jurnal Ilmu Gizi.

44. Nakai, S. dan H.W. Modler. 2000. Food Proteins Processing Applications. Wiley-VCH, Canada.

45. Ndife, J, Udobi, C. Ejikeme, dan N. Amaechi. 2010. Effect of Oven Drying on the Functional and Nutritional Properties of whole Egg and its Components. International Food Research Journal Vol.4 No.5 p.254-257.

46. Nurbaya, S.R. dan T. Estiasih. 2013. Pemanfaatan Talas Berdaging Umbi Kuning (Colocasia esculenta (L.) Schott) dalam Pembuatan Cookies. Jurnal Pangan dan Agroindustri Vol. 1 No.1 p.46-55.

Onwueme, I. C. 1994. Taro Culvation in Asia and the Pacific. http://www.fao.org. Diakses: 09/08/2016.

Permadi, S. N., S. Mulyani, dan A. Hintono. Kadar Serat, Sifat Organoleptik, dan Rendemen Nugget Ayam yang disubstitusi dengan Jamur Tiram Putih (Pleurotus ostreatus). Jurnal Aplikasi teknologi Pangan Vol.1 No.4.

Poedjiadi, A dan T. Supriyanti. 2005. Dasar-Dasar Biokimia. Jakarta: UI Press

Puspitasari, G.G, Wignyanto, B. S. D. Dewanti. 2014. Pemanfaatan Jamur Tiram Putih (Pleurotus ostreatus) sebagai Tepung, Kajian Pengaruh Suhu dan Lama Pengeringan. Jurnal Pangan dan Agroindustri.

Rahmawati, W., Y. A. Kusumastuti, N. Aryanti. 2012. Karakterisasi Pati Talas (Colocasia Esculenta (L) Schott) sebagai Alternatif Sumber Pati Industri di Indonesia. Jurnal Teknologi Kimia dan Industri Vol.1 No.1. p.347-351.

Richana, N, 2012. Araceae \& Dioscorea Manfaat Umbi-umbian Indonesia. Seri Teknoagri, Bogor.

Rosida, T. S, dan D.A. Manggarani. 2008. Pembuatan Cookies Kelapa (Kajian Proporsi Tepung
Terigu :Tepung Ampas Kelapa dan Penambahan Kuning Telur). Jurnal Teknologi Pangan Vol.2 No.1 p.59-65.

Rosida, T. S. dan D.A. Manggarani. 2014. Kajian Kualitas Cookies Ampas Kelapa. Jurnal Rekapangan Vol.8 No.1 p.104-116.

Rust, R.E. 1987. Sausage Product In : The Science of Meat and Meat Product. $3^{\text {rd }}$ Ed. J. F. Price and B. S. Schweigart (ed). Food and Nutrition Press. Inc. Coonnecticut-USA.

Saptoningsih. 2014. Menghilangkan Zat Antinutrisi Pada Talas. Artikel. http://www.bbpplembang.info. Diakses: 09/08/2016.

Schumm W. 1978. Chemistry. Interscience Publisher Inc, New York.

Sefa-Dedeh, S. and Agyic-Sackey, E. K. 2004. Chemical composition and the effect of processing on oxalate content of Cocoyam xanthosoma sagithifolium and Colocasia esculenta cormels. Food Chemistry, 85: 479-487.

Setiyorini, E.I. dan S. Hadi. 2013. Pengaruh Penambahan Udang Rebon dan Jamur Tiram terhadap Hasil Jadi Kerupuk Udang Rebon. Jurnal Boga Vol.2 No.1 p.44-50.

SNI (01-2973-1992). Syarat Mutu Cookies. Standar Nasional Indonesia, Jakarta.

SNI (01-3743-1995). Syarat Mutu Gula Merah. Standar Nasional Indonesia, Jakarta.

SNI (01-3140-2001). Syarat Mutu Gula Putih. Standar Nasional Indonesia, Jakarta.

Soderberg, J. 2013. Functional Properties of Legume Proteins Compared to Egg Proteins and Their Potential as Egg Replacer in Vegan Food. International Food Research Journal No.378 p 12-14.

Soekarto, S.T. 1985. Penilaian Organoleptik untuk Industri Pangan dan Hasil Pertanian. Bhratara Karya Aksara, Jakarta.

Sudarmadji, dkk. 2007. Analisa Bahan Makanan dan Pertanian, Edisi kedua, Cetakan pertama, Penerbit Liberty, Yogyakarta.

Sundari, D.F., Siagian, A., Jumiah. 2014. Pengukuran Nilai Indeks Glikemik Cookies Tepung Talas Belitung (Xanthosoma sagittifolium). Jurnal Gizi, Kesehatan Reproduksi dan Epidemiologi Vol.1 No.4.

Suprihana, E.Sumaryati, R.H. Ekayanti. 2010. Substitusi Jamur Tiram Putih untuk Peningkatan Sifat Kimia dan Kimia Flake dari Maizena. Jurnal Agrika Vol.4 No.1.

Suwetja, I.K. 2011. Biokimia Hasil Perikanan. Media Prima Aksara, Jakarta.

Suwito, M. 2006. Resep Masakan Jamur dari Chef Ternama. PT. Agromedia Pustaka, Jakarta.

Tabrani. 1997. Emping Jagung: Teknologi dan Kendalanya. Institut Teknologi Bandung, Bandung. 
Tooley, P. 1971. Chemistry in Industry Fats, Oil and Waxes. John Murray Albemarie Street, London.

Tranggono dan Sutardi, 1989. Biokimia dan Teknologi Pasca Panen. Pusat Antar Universitas Pangan Dan Gizi, Gadjah Mada University Press. Yogyakarta.

Umniyatie, S., Astuti, D. Pramiadi, Henuhili. 2013. Budidaya Jamur Tiram (Pleuretus sp). Jurnal Inotek Vo.17 No.2.

Utami, I.S. 1990. Warna, Sifat Teksturisasi, dan Profil Sensoris Bahan Pangan. Jurusan Teknologi Pangan dan Hasil Pertanian UGM, Yogyakarta.

Wahyuni, R. 2013. Pengaruh Persentase dan Lama Perendaman dalam Kapur Sirih $\left(\mathrm{CaOH}_{2}\right)$ terhadap Kualitas Keripik Talas Ketan (Colocasia esculanta). Jurnal Pangan dan Agroindustri.

Wardani, C. Dan Suparti. 2014. Kadar Protein Jamur Tiram Putih (Pleurotus ostreatus) pada Media Campuran Serbuk Gergaji, Ampas Tebu, dan Arang Sekam. Skripsi: Fakultas Keguruan dan Ilmu Pendidikan Universitas Muhammadiyah Surakarta.

Widyani, R., dan T. Suciaty. 2008. Prinsip Pengawetan Pangan. Swagati-Press, Cirebon.

Widyastuti, N. dan Koesnandar. 2005. Shiitake dan Jamur Tiram Penghambat Tumor dan Penuruh Kolesterol. PT. Agromedia Pustaka, Depok.

Widyastuti, E., R. Claudia, T. Estiasih, dan D.W. Ningtya. 2015. Karakteristik Biskuit Berbasis Ubi Jalar Orange (Ipomoea batatas L.), Tepung Jagung (Zea mays) Fermentasi, dan Konsentrasi Kuning Telur. Jurnal Teknologi Pertanian Vol.16 No.1.

Winarno, F. G. 1997. Teknologi Produksi dan Kualitas Mi. IPB-Press, Bogor.

Winarno, F.G. 2004. Kimia Pangan dan Gizi. Pernerbit PT. Gramedia Pustaka Utama, Jakarta.

1. Yuliatmoko, W dan D. I. Satyama. 2012. Pemanfaatan Umbi Talas sebagai Bahan Substitusi Tepung Terigu dalam Pembuatan Cookies yang Disuplementasi dengan Kacang Hijau. Jurnal Matematika, Sains, dan Teknologi Vol.13 No.2 p.94-106. 